\title{
The social stratification of the Madurese society and its implications on the usage of Bhasa Madhura
}

\author{
Lukman Fajariyah $^{1^{*}}$ \\ ${ }^{182}$ Department of Interdisciplinary Islamic Studies, UIN Sunan Kalijaga, Indonesia \\ * Corresponding author \\ E-mail address: lukmanfajar9@gmail.com \\ DOI: https://doi.org/10.21107/sml.v3i2.7371
}

\begin{tabular}{|c|c|}
\hline Article Info & Abstract \\
\hline $\begin{array}{l}\text { Keywords: } \\
\text { Structural } \\
\text { functionalism } \\
\text { Social stratification } \\
\text { Madurese } \\
\text { Bhasa Madhura }\end{array}$ & $\begin{array}{l}\text { This paper explored the life of social stratification of the Madurese society } \\
\text { and the usage of Bhasa Madhura (Madurese language) by using two theories, } \\
\text { namely Talcott Parsons' structural functionalism theory and stratification } \\
\text { theory by Paul B. Horton. The research method used in this research was a } \\
\text { qualitative descriptive method. The authors based this research on literature } \\
\text { review and empirical data by observation and interviews. Through data } \\
\text { analysis, the author uncovered several findings. First, the social stratification } \\
\text { styles of the Madurese society in the context of status, class, and occupation } \\
\text { was divided into three types, namely the levels of the oreng kenek, pongghaba, } \\
\text { and parjaji communities. Second, the social stratification styles from religious } \\
\text { context were divided into six types, including keyae, ajji, modin, bindharah, } \\
\text { santre, and banne santre. Third, the usage of Bhasa Madhura in the Madurese } \\
\text { social stratification was divided into different honorifics, from the highest } \\
\text { and most polite honorific to the lowest or impolite honorific. Besides that, the } \\
\text { usage of abhasa (enggi-bunten) styles and ta'abhasa (enja'-iye) styles also occur } \\
\text { in some aspects of Madurese conditional and contextual life. The findings of } \\
\text { this study could be used to advise the preservation of Bhasa Madhura in the } \\
\text { social stratification realm. }\end{array}$ \\
\hline
\end{tabular}

Citation suggestion:

Fajariyah, L. (2020). The social stratification of the Madurese society and its implications on the usage of Bhasa Madhura. Simulacra, 3(2), 165-178. https://doi.org/10.21107/sml.v3i2.7371

Received 30 May 2020; Received in revised form 29 September 2020; Accepted 5 October 2020; Published online 25 November 2020. 


\section{Introduction}

The society's social life always runs dynamically and varies in every era. It is, of course, inseparable from the influence of power or interests of individuals and groups. Social and cultural systems are evidence of the existence of the role of society in interacting, communicating, and socialising in everyday life. One impact of society's roles in social needs is the formation of structures and layers in society. These layers of society establish social stratification, thereby causing the creation of differentiation within the society itself. The differentiation can be in the form of social differentiation, professions, values, religiosity, languages, and so forth.

Social class differentiation affects interactions between communities or individuals with conditions. They adapt according to their social class. For example, people who are in the middle to upper social class status have different ways of interacting and communicating compared to the lowermiddle-class people. Alternatively, it also exists in theinteraction between akeyae (clerics or the head of Islamic boarding school) and a santre (someone who is currently undergoing education at an Islamic boarding school). They are required to adapt because of their different positions. One result of social class strata is the difference in how to behave and communicate with members of certain social classes. This phenomenon is also represented in the social life of the Madurese people.

Madurese society is categorised in a socially stratified society. Madura has highly diverse social class, from the lowest to the highest class. These social layers lead to the diverse roles of society in social activities. In the context of Madurese society, Kuntowijoyo stated that social class is not only found in one's status and occupation. Social class can also be found in the religious aspect as seen in the role of religious leaders in Madurese society. He added that the social stratification of the Madurese community could also be identified through the use of Bhasa Madhura (Kuntowijoyo, 2002). As a logical consequence, this social stratification influences the process of social communication, especially in the use of Bhasa Madhura (Madurese language). Regarding this, the researchers sought to find out the style of social stratification in Madurese society and its implications for the use of Bhasa Madhura through a sociological approach to stratification theory.

Previous studies on the Madurese society mostly focused on the society's character (Azhar, 2009), the role of keyae (clerics) and pesantren (Islamic boarding school) in the context of cultural revitalisation (Ramadlan, 2013), social change in the Madurese agrarian society (Kuntowijoyo, 2002), and the shift in the use of Bhasa Madhura (Raihany, 2015). In general, these studies specifically examined the social phenomena of the Madurese community. The study was focused on the characteristic of the community, language, and the role of the Kyai. Therefore, the author hypothesised that social phenomena which include aspects of community character, language, and the role of the Kyai are an integral part of social life. This article discussed styles of social stratification in Madurese society and their implications for the use of Bhasa Madhura. The author emphasises that the position and contribution of this research were to explore and reveal the phenomenon of social stratification in Madurese society and its implications for the use of Bhasa Madhura in social life. 
Based on the above phenomena, it is necessary to conduct a study on the Madurese community to reveal the existing social stratification styles and their implications for the use of Bhasa Madhura. Therefore, the researchers formulated the following problems; first, what is the style of social stratification of the Madurese community in the context of status, class and occupation? Second, what is the style of social stratification of the Madurese community in a religious context? Third, how is the use of Bhasa Madhura in the social stratification of the Madurese community? The author dissects this problem by using structural functionalism theory and social stratification theory to reveal practice-discursive data with critical analysis.

\section{Method}

The research method used in this research was the descriptive qualitative method by describing the object to produce accurate and comprehensive data. This method was also intended to interpret the phenomena that occur through data collection, data analysis, and data interpretation (Anggito \& Setiawan, 2018). Data collection in this study was carried out through literature study, observation, and interviews. Furthermore, data analysis was carried out in several stages. First, the authors described and analysed the social stratification styles of the Madurese community in the context of status, class and occupation. Second, the authors described and analysed the social stratification styles of the Madurese community in a religious context. Third, the authors described and analysed the use of Bhasa Madhura in the social stratification of the Madurese community. The collected data were examined using two approaches, namely, structural functionalism theory and social stratification theory. In addition, data interpretation was carried out by narrating the finding data into a coherent story.

This research was conducted in Sumenep Madura in 2019. In data collection, the authors used literature study techniques, observation, and informants. The literature study was carried out to explore data about the Madurese community through historical books, scientific works, and articles. At the informant stage, researchers selected informants based on several criteria. These criteria include the Madurese community who are members of a specific social class in status and occupation. Through these informants, the author obtained information about a particular situation or phenomenon (Moehnilabib et al., 1997). The data were presented and analysed based on research questions. The final step was to discuss the result.

\section{Results and Discussion}

\section{The social stratification of Madurese society: Status, class, and occupation}

The social stratification of the Madurese society is divided into three levels, namely oreng kenek, pongghaba, and parjaji (Sofia, 2014). Oreng kenek is considered the lowest level in Madurese society. The people belonging to this layer are people who have non-permanent professions, mostly from the working-class society, farmers, fishermen, craftsmen, and so forth. Farmers and fishermen are usually spread in various tanean lanjang (long shared house yards) (Jonge, 2011). Pongghaba is the middle-class society level. This group is usually has a steady income or works in government agencies, such as civil servants. The nature 
of the relations style of Madurese cultural traditions is more inclined to be socioculturalism, an indicator of the validity of truth in attitude and behaviour (Hidayat, 2013).

Finally, parjaji is the highest level in society. The parjaji group itself is divided into two, the first being those who are has the royal lineage in Madurese kingdoms. They have the title of nobility or sentana (Asdriyatorina et al., 2012). Sentana is the inner circle of the royal family that extends to the grandchildren of the king. Outside these lines, certain degree of nobility does not apply if the titleholder does not hold a position in the current bureaucracy, and they even tend to be forgotten and unknown. The title Raden is generally used for royalties. The banner and ario titles are only used for adult sentana members. Meanwhile, the term Raden Ayu is used for daughters and grandchildren in sentana circles (Kuntowijoyo, 2002). The second part of the parjaji group was people who had positions and ranks during the Dutch colonial period, such as regents, head of the district, and so on.

In the Madurese social system, the three layers of society with different social structures also have different roles and functions in social life. However, in practice, the differentiation of social layers is not a problem because these social conditions reflect the diversity of functions in society. With various stratifications, the Madurese community can adapt to existing social and natural conditions. This phenomenon follows the adaptation principle in structural functionalism theory, which is a system that can overcome critical conditions. The system is required to be able to contextualise itself with the existing situation and environment, and also try to adapt the environment to their needs (Jam'a, 2016). Madurese people also believes that professional differentiation aims to meet basic needs by exchanging goods or services.

In terms of exchange of services, for example, people whose jobs are not permanent can have the opportunity to take dherreb (projects) offered by the pogghaba and parjaji groups, such as house renovation, house cleaning and so on. On the other hand, pogghaba and parjaji also feel the benefits of the project in their interests. Class situations and other conditions remain the same, but the direction an individual worker takes in pursuing his or her interests can vary widely, depending on how he or she can qualify for the work he does (Weber, 2009). This dynamic shows the integration in the social life of the Madurese community which proves that social class differences are seen as a necessity and only function as an individual's appreciation of each other to live a social life. In the aspect of integration, structural functionalism theory combines the principle of adaptation, the principle of achieving goals, and the principle of maintaining social cycle styles (latency) in people's lives (Jam'a, 2016). Therefore, these four principles emphasise the interpenetration of the four functional urgencies or challenges throughout the social system (Ritzer \& Smart, 2012).

The theory of structural functionalism that was raised in 1930 by Talcott Parsons has the view that society is formed as a social system consisting of sub-systems or parts that are interrelated with one another. This theory emphasises the structure of social institutions from various layers or classes of society and ignores conflicts in society. Structural functionalism theory departs from the basic assumption that every stratification 
in a social system functions with one another. In essence, the sub-system or layer of society must have functional integrity that is interconnected; otherwise, stratification is considered non-existent or even lost (Jam'a, 2016).

The social structure describes a wellorganised network of social integration. This process reveals and shows the differences in the social position of a person and others as community members. The differences in social class can be seen from how the relationships between layers of society in channelling their functions. These layers of society empirically have different social relationship functions in order to create social integrity so that the sub-system can run in an organised manner in a complete social system cycle (Jam'a, 2016).

From the nature and status gain in social stratification, the parjaji community from the sentana (royal aristocracy) group tends to have a closed social stratification so that it does not allow the transfer of levels from low to higher levels. Closed social stratification is a layer in society that does not allow the level transfer. This condition usually occurs in caste and feudal societies. At the parjaji level, society is tied to a feudal caste so that each has a function and role in each class or caste. Parjaji's social status or position is automatically acquired or labelled based on lineage without any effort required to achieve that status. This type of status is known as ascribed status, which is a position that is obtained automatically without effort (Ismawati, 2014). Based on historical records, the sentana group was getting weaker when the Dutch began to set foot on the Madura Island and added to the Japanese occupation. At that time, the Sentana group increasingly did not have the power as the holder of sovereignty over the kingdom they led. The Dutch and Japanese colonial practices caused the weakening of the sentana power. Therefore, the discussion about the sentana group is always associated with the era of the Javanese kingdom, which still stood firmly up to the Portuguese colonial period (Zamroni, 2012).

On the other hand, orang kenek's social status is an open social stratification that tends to be democratic. Members of the orang kenek group can freely move between social strata, both vertically and horizontally (Ismawati, 2014). Oreng kenek (lower class people) who have a non-permanent profession with sufficient income can move up to a higher level to become oreng raje (upper-class society). Usually, the form of effort made to change social classes tends to be from the educational side. Oreng kenek can become oreng raje (upper class) because of higher education achievement, which changes social status or position. This change is the acquisition of social status on purpose with efforts or achieved status. Achieved status is a status obtained through deliberate effort (Ismawati, 2014). For example, a position obtained through education, such as a doctor, who earned the title ' $\mathrm{dr}^{\prime}$. A person who can achieve this status will change the views of those around him. They become more respected so that other people do not act carelessly or look down on them. In terms of the realities of life, the Madurese community has strong social solidarity which is reflected in the tradition of sateratanan (brotherhood) and settong dhere (one blood) in the social life of the Madurese community (Mohsi, 2019). In addition, they are guyub (friendly) and hardworking in making ends meet (Azhar, 2009). The Madurese custom favours working together (gotong royong) in completing a project. 


\section{The social stratification of Madurese society: Religious context}

Religion, with its transcendent abilities, can provide a basis for legitimacy for human social existence (Mahasin, 1996). According to Peter L. Berger, religion in society is a form of an effort to build a world, where religion has a unique place in that effort (Berger, 1994). The context of a religious community is undoubtedly different from the conditions of social society in general. Religious people tend to be more active in religious matters and do not play a role in bureaucratic life because they prioritise religious knowledge and serve religion. It shows that each society and culture has different characteristics and beliefs, as can be seen in the religion, followed by the majority of the Madurese (Islam) (Harits, 2018). In a religious society, there is also stratification, just like in the general public. Stratification in the context of religious communities in Madura are keyae, ajji, modin, bindarah, santre, and banne santre.

First, keyae (kyai) are village elites who specifically handle religious rituals. Their knowledge of Islam made them the most respected people in the village. Some of the keyae, apart from conveying their expertise in the field of religion, can also predict fortunes, heal the sick, and lead recitations. Keyae can be grouped into three types; Koran teachers, Koran teachers who teach various kinds of books, and teachers or tarekat leaders. These three types of keyae can be found in Madurese society, but their distribution is rare or unknown (Kuntowijoyo, 2002). In social life, keyae plays a significant role in sustainable development (Ramadlan, 2013). Based on religion, the Madurese people place teachers or religious leaders in a high (respectable) position. This condition refers to the role and function of religious leaders who guide society in religious matters (Hannan \& Abdillah, 2019). Through his charisma, keyae was made an 'inner priest' in the field of 'ubudiyyah and was often asked to solve problems faced by society. This situation further strengthens keyae's role in society because his presence is believed to bring blessings (Susanto, 2017).

Second, ajji (pilgrim) is a general term for someone who has made the pilgrimage to the holy city of Mecca. Hajj is a form of worship that every Muslim who is physically and financially capable must perform. Every year, millions of people from all over the world flock to the holy land (Mecca) (Sadzali, 2018). In many ways, ajji was no different from most people. However, the characteristic that is always visible is clothes. They always wear white hats and wear koko clothes that indicate their social status (Kuntowijoyo, 2002). Third, modin (wedding ceremony leader) is a religious profession that plays a role in organising various programs for community empowerment and is a leader in a wedding ceremony.

Fourth, Bindarah (Islamic boarding school alumni) is a person who has obtained and has completed education at the Islamic boarding school so that he has obtained sufficient religious knowledge but is not at the level of keyae (Sofia, 2014). Fifth, santre (students at Islamic boarding schools) are people who are currently undergoing education at a pesantren to study religious sciences. Sixth, banne santre (non-pesantren santri) are people who have never attended an Islamic boarding school.

In the life of religious people, the process of adaptation, goal achievement, integration, and latency runs in a regular cycle (Syarif, 2017). Religious communities tend to put more emphasis on obtaining religious education and service to religion and society. 
The difference in stratification between the keyae and the santre is considered a blessing. They are even considered as an opportunity for students to get the blessing of knowledge from keyae. Furthermore, vice versa, keyae get the opportunity to practice their knowledge as a service to religion and society.

Regarding keyae as a central figure in the pesantren, his leadership is something unique. The social relationship between the keyae and the santre is carried out based on trust, not because of the patron-client like society in general. Santre obedience to keyae is based more on expecting blessings, for example by kissing the hand of the keyae when shaking hands, visiting the keyae's house, and asking for prayers for specific times (Bahri, 2016).

In the context of a religious society, stratification is hierarchical. The existing levels are the upper level, keyae, to the lower level, the banne santre. Keyae class is closed stratification. In practice, usually, an ulama or keyae from a pesantren will be replaced by their children in the leadership of the pesantren. This social status is ascribed status (Ismawati, 2014), which is obtained automatically and without effort. Even so, keyae children have to fight hard to gain religious knowledge so that they can be equal to ustadz by attending Islamic boarding schools even though they have received the title of lora or gus since birth and will be keyae when they grow up.

On the other hand, the bindharah and santre social classes tend to be open social stratification. A santri can receive education at a school taught by keyae. The process of education in schools is usually taught through recitation at the mosque, where the ustad $z$ reads some religious texts and students imitate line by line (Geertz, 2013). The status and social position of a bindharah and a santre can move up to a higher level and can even become a keyae or modin based on the depth of religious knowledge gained during their pesantren education. After graduating from the pesantren, the existence of a bindharah and a santre will be more respected than the banne santre. When compared to the banne santre, the santre has a superior position in society. This is based on the depth of religious knowledge obtained from pesantren education (Saputra, 2018). Maintaining the dignity or glory of the Madurese community is one form of carrying out religious obligations (Islam). A person is obliged to protect himself and get everything that is his right is an expression of gratitude to God (Rizam, 2013). Therefore, social status is classified as obtaining social status intentionally or also known as achieved status.

Based on such phenomena, it can be seen that social stratification is a concept of differentiating community members based on the status they carry. The layers of social class are seen gradually (vertically). According to Paul B. Horton, layers of society emerge because of the growth and development of social life in a society. However, some classes grew because they were deliberately formulated to achieve common goals. Several factors cause social stratification to emerge by itself, such as intelligence, kinship system, age, and wealth to a certain extent (Ismawati, 2014).

According to Huky (1982), the factors that cause social stratification are racial and cultural differences, professional specialisation, and scarcity. Social stratification is also based on wealth, power, descent and education. These factors make something more appreciated in social life. A person can be respected because of his wealth, power, influence, lineage, and education (Ismawati, 2014). 


\section{The usage of Bhasa Madhura in the Madurese social stratification}

Bhasa Madhura (Madurese language) is one of the Austronesian languages spoken by more than thirteen million speakers or about $5 \%$ of Indonesia's population. Bhasa Madhura has a relatively large number of speakers because it is ranked number four of the most spoken language by Indonesians, below Javanese, Indonesian and Sundanese languages. Nevertheless, this language is not well preserved. This situation is inseparable from several internal and external factors. One of them is the lack of mass media that broadcast or publish writings in Madurese. If the efforts to maintain the Madurese language (preserving) are not optimal, then the Madurese language will experience an inevitable process of destruction and shifting (Mulyadi \& Bukhory, 2019).

Moreover, the social stratification in Madurese society is inseparable with the use of Bhasa Madhura (Madurese language) caused by the vertical segmentation in the society affecting everyday language. The use of language must be appropriate to the context and the interlocutor, based on the social stratification of the society. The mapping the use of language as animplication of social stratification in Madurese society is as follows (Ma'arif, 2015):

First is Keraton (Palace) honorific, such as 'abdi dalem' (me) and 'junan dalem' (you). This term is commonly used in the Sentana Palace circles. Second, high honorific, such as 'abdina' (me) and 'panjenengan' (you), commonly used by pongghaba or subordinates to superiors in the palace or government circles, or santre to keyae. Third, polite honorific, such as 'kaule' (me) and 'sampeyan' (you), are used by young people to older or respected people. Fourth, intermediate honorific, such as the bulha' (me) and 'dhika' (you), are used by older people to younger but respected people, for example, in-laws to his son-inlaw. Fifth, mapas or low honorifics, such as the terms sengko '(me) and ba'na, kakeh, and sedeh (you), are commonly used by older people to younger people, superordinate to subordinates, or among people of the same age. This term is also commonly used by people who are very close to each other.

Other than that, there is also a difference in the use of the Madurese language in some aspects of life, such as in activities, circles, and professions. Purnomo et al. (2013), proposed the following classification;

The usage of the Bhasa Madhura in the family domain

In the family domain, the ta'abhasa (enja'-iye) style is often used. Older people commonly use Madurese such as style to younger people, for example, from parents to children or grandfather to their grandchildren. This type of language style (enja'-iye) is also used by people of the same age or between cousins.

Examples of ta'abhasa (enja'-iye) style used by a grandfather to his grandchildren:

Amsuk (grandfather): cong, melleaghi rokok cap opet $e$ berung, sengkok la tadhek malemma. (grandchildren, buy me the opet brand cigarettes in the stall, I am out of cigarettes).

Febri (grandchild): enggi keh, ekaemma obenga kaule mangkata mellea rokok ka berung. (yes grandfather, 
where is the money? I will buy cigarettes in the stall).

Examples of the ta'abhasa (enja'-iye) style used by a mother to her child:

Sahma (Mother): Jege Vi, se asobbhuwe areya la terang. (wake up Vi, it's time for dawn prayers! It is morning already).

Novi (child): $\quad$ Enggi mak. (Yes mom).

The usage of the Bhasa Madhura in the social domain of neighbourhoods

The use of the Madurese language in the neighbouring realm tends to vary and adapt to the context, for example, age similarity, closeness, and foreignness. The use of the ta'abhasa (enja'-iye) style in neighbouring social contexts usually tends to be used by interlocutors who are the same age or by adults or parents to younger interlocutors where both are close friends.

Example:

Almudeh: sateya polongan jegung din sapa Min? (Who is working on harvesting corn now Min?).

Sutammin: sateya polongan jegung din Jumarie gunong temur. (Now it is Jumari's turn to harvest corn in the eastern fields).

Meanwhile, the Madurese language with the abhasa (enggi-bunten) style tends to be used by speakers with older interlocutors and speakers with one-level interlocutors. In addition, the use of the Madurese language with the abhasa (enggi-bunten) style is also used by adult speakers for younger but foreign interlocutors.
Example:

Zayadi: ngatore lek, dhe'er sotona! (please brother, eat the soto!).

Firman: enggi kak, ngireng. (yes brother, come on).

Madurese language with the abhasa (enggi-bunten) style is also used in formal contexts such as village events, meetings, kompolan, and so on.

Example:

Hasan: samangken kompolan tangge'enna pasera gi? (Village gathering at whose house?).

Syarwan: samangken tangge'enna oreng Masaran laok. (Now the schedule for village arisan in south Masaran).

The usage of Bhasa Madhura in the religious realm

The use of the Madurese language in the realm of religious activities tends to be very high and polite with abhasa (enggibunten) style. The keyae always uses this style in communicating or lecturing to his congregation. Likewise, the congregation also highly upholds the position of a religious leader. As a sign of respect, they use a subtle and polite language style, namely the abhasa (enggi-bunten) style. The use of regional language (Bhasa Madhura) in delivering da'wah by keyae is beneficial and can be easily accepted and understood by the community (Adam, 2018).

Example:

Kyae Ruslan (Preacher): samangken kaule atanya'a dhek para hadirin sadeje, lerres napa bunten 
oreng se taqwa dhek ka ajunan pangeran neka bakal masok soargha? (Now I want to ask all of you, is it true that people who are devout to Allah will go to heaven?).

Jemaah: lerres keh. (correct, kyai).

The usage of Bhasa Madhura in the realm of education

Not much different from the previous classification, the usage of Madurese language in the realm of educational activities in the school environment there are two language styles used, namely ta'abhasa (enja'-iye) and abhasa (enggi-bunten) styles. Both Madurese styles depend on the context or situation of communication and the position of the speaker and interlocutor. For example, communication between a junior teacher and a senior teacher tends to use the abhasa abhasa (enggi-bunten) style. However, among teachers who are already familiar and equal, usually tend to use the ta'abhasa (enja'iye) style. In addition, the use of the ta'abhasa (enja'-iye) style also occurs in teacher-student communication. On the other hand, a student must use the abhasa (enggi-bunten) style when communicating with his teacher. This shows the respect, politeness and politeness of the students' speech to the teacher.

Examples of teacher conversations with students:

Mr Hamid (teacher): kellas tello' deggik bile mare jam istirahat, langsung masok $\mathrm{ka}$ kelas ye soala bedhe pembagian seragam olahraga. (Third graders, after recess, go straight to the classroom because there will be a distribution of sports uniforms).

Student: enggi pak, insyaallah deggik lastare istirahat kaule sareng ca-kanca langsung masok kellas. (OK sir, later after the recess, my friends and I will go straight to class).

Examples of young teacher conversations with the principal:

Mrs. Isna (teacher): manabi sampeyan kasokan, kaule ausule untuk rapat evaluasi kurikulum elaksanaagi tanggel lema' september. (If you wish, I suggest holding a curriculum evaluation meeting on the fifth of September).

Mr. Jailani (principal):enggi, samentara kaule tarema usulanna sampeyan untuk dipertimbangkan, kalangkong atas usulanna gi. (Yes, for now I accept your proposal for consider a tion, thank you for the suggestion).

The usage of Bhasa Madhura in the realm of government

The use of the Madurese language in the realm of government agencies tends to be conditional and contextual because 
the Indonesian language is also used in government agencies. The ta'abhasa (enja'iye) and the abhasa (enggi-bunten) styles characterise communication in the realm of government. However, it depends on several criteria, as previously explained. The ta'abhasa (enja'-iye) style is usually used by speakers who have known each other for a long time with their interlocutors (colleagues) and also by parents to younger interlocutors. Meanwhile, the abhasa style (enggi-bunten) is usually used by speakers of equal age or by younger people to older ones and vice versa.

Examples of using ta'abhasa (enja'-iye) styles:

Mr. Nurul: jeriya beremma sistem pengalokasian dana sosial se khususaghi untuk masyarakat se korang mampu. (What is the system for allocating special social funds for the poor).

Mr.Sugiyono: sistem pengalokasian dana sosial se khususaghi untuk masyarakat se korang mampu reya didasarkan kalaben surat keterangan tidak mampu se ekeluaragi oleh pemerintah desa. (the special social fund allocation system for the poor is based on a poverty certificate issued by the village government).

Examples of using abhasa (enggi-bunten) styles:

Mr. Busyro: samangken kaule menghimbau dhek sadeje anggota rapat untuk menyampaikan pendapat epon se ahubungan sareng pengelolaan dana desa. (Now I urge all members of the meeting to express their opinion on the management of village funds).

Mr. Andi: enggi pak kaule setuju. (yes sir, I agree).

Based on the example above, we can see that the use of both abhasa and ta'abhasa style of Bhasa Madhura can be based on aspects of education, age, and social background (Effendy, 2014). Even so, there are differences in the patterns of use of the Madurese language in each area of social life activity or at the level of certain social classes. Language fluency can be seen from the function and use of the language. The more often it is used, the more fluent the language speaker will be. This is also an effort to preserve language in the community.

\section{Conclusion}

Social stratification forms a social system of society as a result of the diversity of layers of society that have various roles and functions. Thus, the social system can run in regular and structured cycles abstractly. Data analysis proves that each social class or class of society in Madura has different characteristics. There are two characteristics of stratification, namely closed stratification and open stratification.

The stratified layers of Madurese society have implications for the use of the Madurese language, which differentiates each level. This is evident that each layer of society in the social stratification of the Madurese community has a different level of language. The use of abhasa (enggi-bunten) and ta'abhasa (enja'-iye) patterns that occur in several aspects of Madurese life is conditional and contextual. The use of Bhasa Madhura occurs in the realm of family, social neighbours, 
religion, education, and government or bureaucracy. Besides that, in general, social stratification is not seen as a problem, but only as an appreciation of individuals for mutual understanding in living a social life. In short, it can be concluded that social stratification in Madurese society arises because of the growth and development of social life that exists in society and likewise with the use of Bhasa Madhura, which is an implication of the social stratification of society. Thus, speakers of Bhasa Madhura must adjust the use of style according to the context of their communication. This certainly has a positive impact on the preservation of the Bhasa Madhura used in every social class.

\section{Declaration of Ownership}

This article is our original work.

\section{Conflict of Interest}

There is no conflict of interest to declare in this article.

\section{Ethical Clearance}

This study was approved by the institution.

\section{References}

Adam, S. (2018). Efektifitas bahasa Gorontalo dalam penyampaian materi dakwah. Mediakita, 2(1), 17-25. https://doi. org/10.30762/mediakita.v2i1.979

Anggito, A., \& Setiawan, J. (2018). Metodologi penelitian kualitatif. CV Jejak.

Asdriyatorina, A., Dzulkarnain, I., \& Prananta, A. W. (2012). Jaringan sosial bangsawan di pemerintahan Kabupaten Sumenep Madura. Dimensi, 4(1), 1-14. https://www.academia.edu/13857021/ Jaringan_Sosial_Bangsawan_Di_ Pemerintahan_Kabupaten_Sumenep_ Madura?auto=download

Azhar, I. N. (2009). Karakter masyarakat Madura dalam syair-syair lagu daerah Madura. Atavisme, 12(2), 217-228. https://doi.org/10.24257/atavisme. v12i2.171.217-228

Bahri, S. (2016). Perspektif teori struktural fungsionalisme tentang ketahanan sistem pendidikan pesantren. Miqot:

Jurnal Ilmu-Ilmu Keislaman, 40(1), 88-105. https://doi.org/10.30821/miqot.v40i1.221

Berger, P. L. (1994). Langit suci-agama sebagai realitas sosial. LP3ES.

Effendy, M. H. (2014). Analisis kearifan lokal dalam konteks tindak tutur bahasa Madura. Okara, 8(2), 19-44.

Geertz, C. (2013). Agama Jawa: Abangan, santri, priyayi dalam kebudayaan Jawa. Komunitas Bambu.

Hannan, A., \& Abdillah, K. (2019). Hegemoni religio-kekuasaan dan transformasi sosial: Mobilisasi jaringan kekuasaan dan keagamaan kyai dalam dinamika sosio-kultural masyarakat. Sosial Budaya, 16(1), 9. https://doi.org/10.24014/ sb.v16i1.7037

Harits, I. W. (2018). Religious and moral values in Madura folktales. Sirok Bastra, 1(2), 243-249. https://doi.org/10.37671/ sb.v1i2.27

Hidayat, A. R. (2013). Makna relasi tradisi budaya masyarakat Madura dalam perspektif ontologi Anton Bakker dan relevansinya bagi pembinaan jati diri orang Madura. Filsafat, 23(1), 21-32. https://doi.org/10.22146/jf.13155

Ismawati, E. (2014). Stratifikasi sosial dan teori stratifikasi sosial. http://estiisma.blogspot. com/2014/11/setiap-masyarakatsenantiasa-mempunyai.html 
Jam'a, I. (2016). Pesantren dan pengajian ta'aruf studi tentang eksistensi biro jodoh di pondok pesantren mahasiswa Al-jihad Surabaya [UIN Sunan Ampel Surabaya]. http:// digilib.uinsby.ac.id/id/eprint/3955

Jonge, H. De. (2011). Garam kekerasan dan aduan sapi. LKiS.

Kuntowijoyo. (2002). Perubahan sosial dalam masyarakat agraris Madura 1850-1940. Mata Bangsa.

Ma'arif, S. (2015). The history of Madura: Sejarah panjang Madura dari kerajaan, kolonialisme sampai kemerdekaan. Araska.

Mahasin, A. (1996). Ruh Islam dalam budaya bangsa: Aneka budaya nusantara. Yayasan Festival Istiqlal.

Moehnilabib, M., Mukhadis, A., Ibnu, S., Suparno, Rofiuddin, A., \& Sukarnyana, I. W. (1997). Dasar-dasar metodologi penelitian (pertama). Lembaga Penelitian IKIP Malang.

Mohsi, M. (2019). Langghar, kophung, dan bhaqaf: Konservasi kebudayaan khazanah keislaman Madura. Sabda : Jurnal Kajian Kebudayaan, 14(1), 14. https:// doi.org/10.14710/sabda.14.1.14-20

Mulyadi, M., \& Bukhory, U. (2019). Stratifikasi sosial ondhâg bâsa bahasa Madura. Nuansa: Jurnal Penelitian Ilmu Sosial dan Keagamaan Islam, 16(1), 1. https://doi.org/10.19105/nuansa. v16i1.2403

Purnomo, J. E., Sariono, A., Sofyan, A., Indonesia, J. S., Sastra, F., \& Jember, U. (2013). Pemakaian bahasa pada masyarakat Madura di desa Kedungdowo Kecamatan Arjasa, Kabupaten Situbondo. 1(1), 1-13. http://repository.unej.ac.id/ handle/123456789/60796

Raihany, A. (2015). Pergeseran penggunaan bahasa Madura di kalangan anak- anak sekolah dasar negeri di desa Pangarangan Kecamatan, Kota Sumenep. Nuansa,
12(1), 47-74. https://doi.org/http://dx.doi. org/10.19105/nuansa.v12i1.697

Ramadlan, M. F. S. (2013). Revitalisasi dimensi budaya dalam pembangunan berkelanjutan di Madura melalui peran kiai dan pesantren. Karsa: Journal of Social and Islamic Culture, 21(1), 73-87. https://doi.org/10.19105/karsa.v20i2.32

Ritzer, G., \& Smart, B. (2012). Handbook teori sosial. Nusa Media.

Rizam, M. M. (2013). Perubahan sosial etnik Madura dalam lirik lagu kontemporer berbahasa Madura. Pendidikan Humaniora, 1(2), 109-116. https://doi. org/10.17977/jph.v1i2.3984

Sadzali, A. M. (2018). Kelas haji kelas sosial: Sejarah haji dari zaman kolonial hingga kini ditinjau dari kajian kritis kapitalisme. Tsaqofah dan Tarikh: Jurnal Kebudayaan dan Sejarah Islam, 3(1), 25. https://doi. org/10.29300/ttjksi.v3i1.1551

Saputra, E. (2018). Stratifikasi sosial ditinjau dari aspek santri dan bukan santri di desa Wargabinangun, Kabupaten Cirebon. SAP (Susunan Artikel Pendidikan), 3(2), 163-169. https://doi.org/10.30998/sap. v3i2.3037

Sofia, G. A. (2014). Stratifikasi sosial masyarakat Madura. https://www. kompasiana.com/gitaaidansofiana/ 54f94402a3331176178b495e/stratifikasisosial-masyarakat-madura

Susanto, E. (2017). Kepemimpinan (kharismatik) kyai dalam perspektif masyarakat Madura. Karsa, XI(1), 30-40. $\quad$ https://doi.org/http://dx.doi. org/10.19105/karsa.v11i1.146

Syarif, Z. (2017). Manajemen kepemimpinan kiai dan kontribusinya terhadap mutu pendidikan pesantren. Fikrotuna, 6(2), 521-531. https://doi.org/10.32806/jf.v6i2. 3112

Weber, M. (2009). Sosiologi. Pustaka Pelajar. 
Zamroni, I. (2012). Dinamika elit lokal Madura. Masyarakat: Jurnal Sosiologi, 17(1), 23-48. https://doi.org/10.7454/mjs. v17i1.3744 